\title{
Effect of varying dietary crude protein and metabolizable energy levels on leg abnormalities and performance in broiler chickens
}

\author{
Efecto de niveles dietarios variables de proteína cruda y energía metabolizable sobre las anomalías en \\ piernas y comportamiento productivo del pollo de engorde
}

\section{Efeito de diferentes níveis de proteína bruta e energia metabolizável da dieta sobre a anormalidades de pernas e comportamento produtivo de frangos de corte}

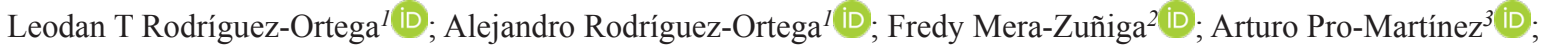 \\ Filogonio J Hernández-Guzmán ${ }^{1}$ iD; Eliseo Sosa-Montes ${ }^{4}$ D; Fernando González-Cerón ${ }^{4}$ iD; Hector Leyva-Jimenez ${ }^{5 *}$ (D). \\ ${ }^{1}$ Universidad Politécnica de Francisco I. Madero. Tepatepec, Hidalgo, km 2, carretera Tepatepec-San Juan Tepa, México. C. P. 42660.
${ }^{2}$ Tecnológico Nacional de México, Campus Tecomatlán, Tecomatlán Puebla, México, C.P. 74870.
${ }^{3}$ Colegio de Postgraduados, Campus Montecillo, km 36.5, carretera México-Texcoco, Montecillo, Texcoco, Estado de México. C. P. 56230.
${ }^{4}$ Universidad Autónoma Chapingo, Departamento de Zootecnia, km 38.5, carretera México-Texcoco, Chapingo, Estado de México. C. P. 56230.
${ }^{5}$ Departamento de Investigación y Desarrollo, Grupo Nutec, El Marqués, Querétaro, México, C. P. 76246.
}

To cite this article:

Rodríguez-Ortega LT, Rodríguez-Ortega A, Mera-Zuñiga F, Pro-Martínez A, Hernández-Guzmán FJ, Sosa-Montes E, GonzálezCerón F, Leyva-Jimenez H. Effect of varying dietary crude protein and metabolizable energy levels on leg abnormalities and performance in broiler chickens. Rev Colomb Cienc Pecu 2022; 35(3): 153-164. DOI: https://doi.org/10.17533/udea.rccp.v35n3a01

\begin{abstract}
Background: Nutrient restriction is a common strategy to prevent metabolic disorders in fast growing broiler chickens, but limited information is available regarding the impact of diets with low protein and energy on leg abnormalities. Objective: Two experiments were conducted to evaluate the effect of varying crude protein (CP) and metabolizable energy (ME) levels on gastrocnemius tendon (GTeBS) and tibia breaking strength (TiBS), gait score (GS) and valgus/varus angulation (VAng). Methods: In Experiment 1, eight-d-old Ross 308 broilers $(n=90)$ were randomly assigned into three treatments: $13 / 2,900$ (13\% CP and 2,900 kcal ME kg-1 of diet), 17/3,000 (17\% CP and 3,000 kcal ME kg-1 of diet), and 21/3,025 or control (21\% $\mathrm{CP}$ and 3,025 kcal ME kg-1 of diet). In Experiment 2, six-d-old Ross 308 chickens ( $\mathrm{n}=192)$ were randomly distributed into two treatments: $16 / 3,000 ; 16 \% \mathrm{CP}$ and 3,000 kcal ME kg-1 of diet and 21/3,000 or control; $21 \% \mathrm{CP}$ and 3,000 kcal ME kg-1 of diet. In both experiments data were analyzed as one-way ANOVA. Results: In Experiment 1, broilers in the 17/3,000 and control treatments had similar ( $\mathrm{p}>0.05$ ) GTeBS (202 and $224 \mathrm{~N}$, respectively), and TiBS (338 and $332 \mathrm{~N}$, respectively).
\end{abstract}

Received: November 28, 2020; accepted: September 7, 2021

*Corresponding author. Av. Del Marqués 32, Fracc. Industrial Bernanrdo Quintana, El Marqués, QRO. 76246. Tel.: 5582621538. Email:ing.leyva531@gmail.com 
Birds in the 13/2,900 treatment showed higher GS (lower walking ability; 80\% of birds with score $>3$ ), and greater VAng (53\% of birds with score $>2)$ than broilers in the control treatment $(0 \%$ of birds with GS score $>3$ and $0 \%$ of birds with VAng score $>2$ ). Experiment 2, broilers in the 16/3,000 showed similar VAng, GS and TiBS than birds in the control treatment. However, birds in the $16 / 3,000$ treatment showed lower $(-26 \%)$ GTeBS than birds in the control treatment $(p<0.05)$. Conclusions: Feeding broilers with $16 \% \mathrm{CP}$ and 3,000 kcal ME kg-1 of diet did not affect tibia breaking strength, gait score and valgus/varus angulation. A diet containing 16\% CP or less and 2,900-3,000 kcal ME kg-1 reduces tendon and tibia breaking strength.

Keywords: breaking strength; broiler; crude protein; gait; gastrocnemius tendon; leg abnormality; metabolizable energy; nutrient restriction; tibia; valgus/varus angulation; valgus-varus deformity.

\section{Resumen}

Antecedentes: La restricción de nutrientes es una estrategia común para prevenir trastornos metabólicos en pollos de engorde, sin embargo, se dispone de información limitada sobre el impacto de las dietas bajas en proteína y energía en las anomalías de piernas. Objetivo: Se llevaron a cabo dos experimentos para evaluar el efecto de niveles variables de proteína cruda (PC) y energía metabolizable (EM) en la fuerza de rotura del tendón del gastrocnemio (GTeBS) y tibia (TiBS), la evaluación de marcha (GS) y la angulación en valgus/varus (VAng). Métodos: En el Experimento 1, pollos de engorde Ross 308 de ocho días de edad ( $\mathrm{n}=90)$ se asignaron al azar en tres tratamientos: $13 / 2.900 ; 13 \%$ PC y $2.900 \mathrm{kcal} \mathrm{ME} \mathrm{kg}^{-1}$ de dieta, $17 / 3.000 ; 17 \%$ PC y $3.000 \mathrm{kcal} \mathrm{ME} \mathrm{kg}^{-1}$ de dieta y 21/3.025 o control; 21\% PC y $3.025 \mathrm{kcal} \mathrm{ME} \mathrm{kg}^{-1}$ de dieta. En el Experimento 2 , pollos Ross 308 de seis días de edad $(\mathrm{n}=192)$ se distribuyeron aleatoriamente en dos tratamientos: 16/3.000; $16 \%$ PC y $3.000 \mathrm{kcal}$ ME kg-1 de dieta y 21/3.000 o control; $21 \%$ PC y $3.000 \mathrm{kcal} \mathrm{ME} \mathrm{kg}^{-1}$ de dieta. En ambos experimentos los datos se analizaron como ANOVA de una vía. Resultados: En el Experimento 1, los pollos de los tratamientos 17/3.000 y control tuvieron GTeBS (202 y $224 \mathrm{~N}$, respectivamente) y TiBS (338 y $332 \mathrm{~N}$, respectivamente) similares ( $>>0,05)$. Las aves del tratamiento $13 / 2.900$ mostraron mayor GS (menor capacidad para caminar; $80 \%$ de las aves con puntaje $>3$ ) y mayor VAng (53\% de las aves con puntaje $>2$ ) que los pollos del tratamiento control ( $0 \%$ de aves con un puntaje GS $>3$ y $0 \%$ de aves con un puntaje VAng $>2$ ). En el Experimento 2, los pollos del 16/3.000 mostraron VAng, GS y TiBS similares a los de las aves del tratamiento control. Sin embargo, las aves del tratamiento 16/3.000 mostraron menor ( $-26 \%)$ GTeBS que las aves control ( $p<0,05)$. Conclusiones: La alimentación de pollos de engorde con 16\% PC y $3.000 \mathrm{kcal} \mathrm{EM} \mathrm{kg}^{-1}$ de dieta no afecta la resistencia a la ruptura de la tibia, la marcha y la angulación valgus/varus. La dieta formulada con 16\% de PC o menos y 2.900-3.000 kcal de EM kg-1 reduce la resistencia a la ruptura del tendón y de la tibia.

Palabras clave: angulación en valgo/varo; anomalía en patas; deformidad del valgo-varo; energía metabolizable; marcha; pollo de engorde; proteína cruda; resistencia a la rotura; restricción de nutrientes; tendón del gastrocnemio; tibia.

\section{Resumo}

Antecedentes: A restrição de nutrientes é uma estratégia comum para prevenir distúrbios metabólicos em frangos de corte, no entanto, há informações limitadas disponíveis sobre o impacto de dietas de baixa proteína e baixa energia nas anormalidades de pernas destas aves. Objetivo: Dois experimentos foram realizados para avaliar o efeito de diferentes níveis de proteína bruta (PB) e energia metabolizável (EM) em força de ruptura do tendão do músculo gastrocnêmio (GTeBS), forca de ruptura da tíbia (TiBS), gait score (GS) e angulação em valgus/varus (VAng). Métodos: Experimento 1, foram utilizados 308 frangos de corte machos da linhagem Ross com oito dias de idade $(\mathrm{n}=90)$ distribuidos aleatoriamente em três tratamentos: dieta controle com $21 \%$ PB e 3.025 kcal EM kg-1 13/2.900; dieta con 13\% PB e 2.900 kcal EM kg-1, y 17\% PB e $3.000 \mathrm{kcal} \mathrm{EM} \mathrm{kg}^{-1}$. Experimento 2, foram utilizados 308 frangos de corte da linhagem Ross com seis dias de idade $(\mathrm{n}=192)$ distribuídos aleatoriamente em dois tratamentos: dieta controle con $21 \% \mathrm{~PB}$ e $3.000 \mathrm{kcal} \mathrm{EM} \mathrm{kg}^{-1}$ e dieta com $16 \% \mathrm{~PB}$ e $3.000 \mathrm{kcal} \mathrm{EM} \mathrm{kg}^{-1}$. Em ambos os experimentos, os dados foram submetidos a ANOVA. Resultados: Experimento 1, os frangos de corte submetidos ao dos tratamentos 17/3.000 e controle nao apresentaram diferencas significativas ( $\mathrm{p}>0,05)$ para as variáveis GteBS $(202$ y $224 \mathrm{~N}$, respectivamente) e TiBS (338 y $332 \mathrm{~N}$, respectivamente). Os frangos submetidos ao 13/2.900 apresentaram maior frequência de GS (menor capacidade de locomocao; $80 \%$ das aves com pontuação $>3$ ) e maior VAng (53\% das aves com pontuação>2) do que os frangos do tratamento controle ( $0 \%$ das aves com pontuação GS>3 e $0 \%$ das aves com pontuação VAng $>2$ ). Experimento 2 , os frangos do 16/3.000 apresentaram VAng, GS e TiBS semelhantes aos das aves do tratamento controle. Entretanto, as aves do tratamento 16/3.000 apresentaram GTeBS mais baixo (-26\%) em comparacao as aves do tratamento de controle ( $\mathrm{p}<0,05)$. Conclusões: A dieta com 16\% PB e $3.000 \mathrm{kcal} \mathrm{EM} \mathrm{kg}^{-1}$ não afetou a forca de ruptura da tíbia, gaite score marcha e angulação em valgus/varus de frangos de corte. Uma dieta com níveis de 16\% de PB ou menos e 2.900-3.000 kcal EM kg-1 reduziu a resistência à ruptura do tendão e a resistência de tibia de frangos de corte.

Palavras-chave: angulação em valgo/varo; anormalidades de pernas; deformidade em valgo/varo; energia metabolizável; força de quebra; frango de corte; marcha; proteína bruta; resistência de tíbia; restrição de nutrientes; tíbia. 


\section{Introduction}

Reduction of crude protein (CP) and metabolizableenergy (ME) in the dietisacommon strategy to decrease metabolic disorders, such as ascites (Sahraei, 2012). However, reduction of these nutrients is also related with reduced performance (Jackson et al., 1982). Research studies conducted on the optimum level of $\mathrm{CP}$ and $\mathrm{ME}$ in broiler chicken diets regarding skeletal development and integrity are not conclusive, as different concentrations of $\mathrm{CP}$ and $\mathrm{ME}$ in the diet could modify the deposition rate of collagen and other important structural proteins (Rath et al., 2000). Bruno et al. (2007) showed that broilers fed $18.5 \% \mathrm{CP}$ and 3,200

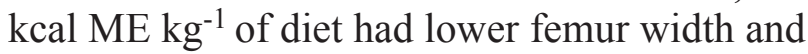
humerus weight compared to control broilers (22\% CP and 2,950 kcal ME kg-1 of diet). Venäläinen et al. (2006) found that feeding broilers with low concentrations of $\operatorname{ME}(2,632$ or 2,831 kcal kg-1) significantly decreased live weight but did not affect walking ability or tibia breaking strength. On the other hand, Banerjee et al. (2013) did not find differences in body weight gain and final live weight of chickens fed $16,18,20$ or $21 \%$ CP for 13 weeks. Scarce studies related to gastrocnemius tendon and tibia breaking strength, gait score (indicator of walking ability) and valgus/varus angulation in broilers fed varying levels of $\mathrm{CP}$ and $\mathrm{ME}$ have been reported. Low dietary CP concentration may be used as an alternative to minimize production costs (Gardzielewska et al., 2005), reduce environmental pollution due to lower nitrogen excretion (Belloir et al., 2017), and reduce the risk of metabolic disorders (Sahraei, 2012). We hypothesize that chickens fed levels close to $16 \% \mathrm{CP}$ and $3,000 \mathrm{kcal} \mathrm{ME} \mathrm{kg}^{-1}$ of diet will have similar gastrocnemius tendon and tibia breaking strength, gait score, valgus/varus angulation, mortality and performance than those fed 21\% CP and 3,000-3,025 kcal ME kg-1 of diet (common commercial starter diet levels). Therefore, the aim of this study was to evaluate the effect of varying dietary CP and ME levels on leg abnormalities and performance of starting broiler chickens.

Rev Colomb Cienc Pecu 2022; 35(3, Jul-Sep):153-164 https://doi.org/10.17533/udea.rccp.v35n3a01

\section{Materials and Methods}

\section{Ethical Considerations}

The experimental procedures followed the standards for ethics, biosafety, and animal wellbeing of the Official Mexican Standard (NOM-062-ZOO-1999; 2001) for the use of animals in research. Euthanasia procedures were performed according to the Mexican Official Norm (NOM-033-SAG/ZOO-2014, 2015).

\section{Poultry facilities and management}

Two experiments were carried out at the poultry research unit of Colegio de Postgraduados, Campus Montecillo, Estado de México, MX $\left(98^{\circ}\right.$ $48^{\prime} 27^{\prime \prime} \mathrm{W}$ and $\left.19^{\circ} 48^{\prime} 23^{\prime \prime} \mathrm{N}\right)$, located at an altitude of 2,278 $\mathrm{m}$ above sea level. In Experiment 1, the birds were housed in $3 \times 1 \mathrm{~m}$ pens and in Experiment 2, birds were housed in $1.5 \times 1 \mathrm{~m}$ pens. In both experiments, new wood-shavings were used as the bedding material. The lighting program was $23 \mathrm{~h}$ light, $1 \mathrm{~h}$ dark throughout the experimental period ( 8 to $51 \mathrm{~d}$ of age for Exp. 1 and 6 to $46 \mathrm{~d}$ of age for Exp. 2). At the beginning of the experiments, the house temperature was maintained at $32^{\circ} \mathrm{C}$ and then it was reduced $\left(2^{\circ} \mathrm{C}\right.$ per week) to $24^{\circ} \mathrm{C}$. The chickens were housed under a curtain-ventilation system. Bell drinkers and hanging cylindrical feeders (111 and $121 \mathrm{~cm}$ in circumference, respectively) were used; water and feed were offered ad libitum.

\section{Experimental design}

At the time of arrival to the experimental facilities, the chickens were allocated in a common pen and offered a basal pre-starter corn-soy diet. After 8 or 6 days (Exp. 1 and 2, respectively), the chickens were weighed and average body weight (BW) was calculated. This average BW was then used to create groups of chicks with similar ( $p>0.05)$ starting weight and distributed in a completely randomized design. In Experiment 1, ninety Ross-308 chicks (8-d-old; straight-run; male and female) were randomly assigned to three treatments ( 3 replicates per treatment, 10 birds per replicate): 1) 13/2,900;13\% crude protein (CP) and 2,900 kcal metabolizable energy (ME) 
$\mathrm{kg}^{-1}$ of diet, 2) $17 / 3,000 ; 17 \% \mathrm{CP}$ and $3,000 \mathrm{kcal}$ ME kg-1 of diet and 3) 21/3,025 or control; 21\% $\mathrm{CP}$ and 3,025 kcal ME kg-1 of diet. In Experiment 2 , one hundred and ninety-two male Ross-308 chicks (6-d-old) were randomly distributed into 2 treatments ( 8 replicates per treatment, 12 birds per replicate): 1) $16 / 3,000 ; 16 \% \mathrm{CP}$ and 3,000 kcal ME kg-1 of diet and 2) 21/3,000 or control; $21 \% \mathrm{CP}$ and 3,000 kcal ME kg-1 of diet.

\section{Dietary treatments}

All diets were formulated to meet or exceed the NRC (1994) requirements for broilers, except for $\mathrm{CP}$ and $\mathrm{ME}$ which varied based on experimental treatment. In both trials, synthetic amino acids were added to treatments $13 / 2,900,17 / 3,000$ and $16 / 3,000$ to balance their concentration to meet NRC (1994) nutrient recommendations.

Experiment 1. The starter phase lasted 21 d (from 8 to 29 d of age) during which the 3 experimental diets with different concentrations of CP and ME were offered. The finisher period followed at the end of the starter phase (30 to 51 d of age) where the chickens were fed a common diet containing 19\% CP and 3,100 kcal ME kg-1 (Table 1).

Experiment 2. The starter phase lasted 21 d (from 6 to $27 \mathrm{~d}$ of age) during which the 2 experimental diets with different concentration of CP and ME were offered. Similar to Exp.1, the chickens were offered a common basal finisher diet containing 19\% CP and 3,050 $\mathrm{kcal} \mathrm{ME} \mathrm{kg}^{-1}$ from 28 to $46 \mathrm{~d}$ of age (Table 2 ).

Table 1. Composition of experimental diets (Experiment 1) ${ }^{1}$.

\begin{tabular}{lcccc}
\hline & \multicolumn{3}{c}{ Starter (8-29 d of age) } & Finisher (30-51 d of age) \\
\hline Ingredients (\%) & $\mathbf{1 3 / 2 , 9 0 0}$ & $\mathbf{1 7 / 3 , 0 0 0}$ & $\mathbf{2 1 / 3 , 0 2 5}$; Control & Basal \\
\hline Yellow Corn & 63.00 & 62.00 & 54.00 & 61.11 \\
Dehulled Soybean meal & 15.00 & 24.00 & 37.00 & 31.38 \\
Soybean oil & 4.85 & 3.84 & 3.31 & 2.98 \\
Calcium carbonate & 1.60 & 1.73 & 1.69 & 1.34 \\
Dicalcium phosphate & 1.58 & 1.75 & 1.67 & 1.57 \\
L-Arginine & 0.71 & 0.38 & 0.08 & 0.00 \\
L-Lysine-HCI & 1.75 & 1.22 & 0.51 & 0.11 \\
L-Threonine & 0.53 & 0.37 & 0.16 & 0.09 \\
DL-Methionine & 0.53 & 0.49 & 0.31 & 0.09 \\
L-Tryptophan & 0.15 & 0.09 & 0.02 & 0.00 \\
${ }^{2}$ Mineral premix & 0.15 & 0.15 & 0.15 & 0.20 \\
${ }^{3}$ Vitamin premix & 0.15 & 0.15 & 0.15 & 0.20 \\
Choline chloride $(75 \%)$ & 0.21 & 0.21 & 0.21 & 0.21 \\
Coccidiostat & ${ }^{*}$ & 0.05 & 0.05 & 0.05 \\
Xanthophlls & 0.05 & 0.00 & 0.00 & 0.37 \\
Salt (NaCl) & 0.00 & 0.30 & 0.30 & 0.30 \\
Sand & 0.30 & 2.95 & 0.00 & 0.00 \\
\hline
\end{tabular}

${ }^{1}$ In the starting period, the calculated diet composition was as follows: CP content: 13,17 and 21\%. Energy: 2,900, 3,000 and 3,025 kcal of ME kg-1, respectively. The finishing diet contained: 19\% CP and 3,100 kcal of ME kg-1. Synthetic amino acids added to meet or exceed NRC requirements (1994).

${ }^{2}$ Mineral premix (per kg of premix): Zn $100 \mathrm{~g}$; Fe $50 \mathrm{~g}$; Cu $10 \mathrm{~g}$; Mn $100 \mathrm{~g}$; I $1 \mathrm{~g}$.

${ }^{3}$ Vitamin premix (per kg of premix): vit. A, 24,000,000 IU; vit. D3 8,000,000 IU; pyridoxine, 8 g; thiamine, 6 g; riboflavin, $16 \mathrm{~g}$; niacin , $100 \mathrm{~g}$; cyanocobalamin, $60 \mathrm{mg}$; menadione, $10 \mathrm{~g}$; calcium pantothenate, $28 \mathrm{~g}$; folic acid, $3 \mathrm{~g}$.

${ }^{¥}$ Coccidiostat, Olistimax ${ }^{\circledR}$, PiSA Agropecuaria, Guadalajara, Jalisco, Mexico. 
Table 2. Composition of experimental diets (Experiment 2$)^{1}$.

\begin{tabular}{lccc}
\hline \multirow{2}{*}{ Ingredients (\%) } & \multicolumn{2}{c}{ Starter (6-27 d of age) } & Finisher (28-46 d of age) \\
\cline { 2 - 4 } & $\mathbf{2 1 / 3 , 0 0 0 ;}$ Control & $\mathbf{1 6 / 3 , 0 0 0}$ & Basal \\
\hline Yellow Corn & 58.03 & 73.04 & 63.93 \\
Dehulled Soybean meal & 35.82 & 19.97 & 30.29 \\
Soybean oil & 1.92 & 0.00 & 1.74 \\
Calcium carbonate & 1.35 & 3.16 & 1.42 \\
Dicalcium phosphate & 1.92 & 2.02 & 1.36 \\
L-Lysine-HCI & 0.17 & 0.68 & 0.16 \\
DL-Methionine & 0.18 & 0.24 & 0.12 \\
L-Threonine & 0.02 & 0.25 & 0.00 \\
L-Tryptophan & 0.00 & 0.06 & 0.00 \\
Salt (NaCl) & 0.35 & 0.35 & 0.35 \\
${ }^{2}$ Vitamin premix & 0.03 & 0.03 & 0.03 \\
${ }^{3}$ Mineral premix & 0.06 & 0.06 & 0.06 \\
Xanthophylls & 0.00 & 0.00 & 0.40 \\
Choline chloride (75\%) & 0.10 & 0.10 & 0.10 \\
Coccidiostat ${ }^{*}$ & 0.05 & 0.05 & 0.05 \\
\hline
\end{tabular}

${ }^{1}$ In the starting period, the calculated diet composition was as follows: CP content: 13, 17 and 21\%. Energy: 2,900, 3,000 and 3,025 $\mathrm{kcal}$ of ME kg-1, respectively. The finishing diet contained: $19 \% \mathrm{CP}$ and 3,100 kcal of ME kg-1. Synthetic amino acids added to meet or exceed NRC requirements (1994).

${ }^{2}$ Mineral premix (per kg of premix): Zn 100 g; Fe 50 g; Cu 10 g; Mn 100 g; I 1 g.

${ }^{3}$ Vitamin premix (per kg of premix): vit. A, 24,000,000 IU; vit. D3 8,000,000 IU; pyridoxine, 8 g; thiamine, $6 \mathrm{~g}$; riboflavin, $16 \mathrm{~g}$; niacin , $100 \mathrm{~g}$; cyanocobalamin, $60 \mathrm{mg}$; menadione, $10 \mathrm{~g}$; calcium pantothenate, $28 \mathrm{~g}$; folic acid, $3 \mathrm{~g}$.

${ }^{\sharp}$ Coccidiostat, Olistimax ${ }^{\circledR}$, PiSA Agropecuaria, Guadalajara, Jalisco, Mexico.

\section{Leg abnormality assessment}

Gastrocnemius tendon (GTeBS) and tibia breaking strength (TiBS). A total of 15 (5 birds per replicate pen) and 16 (2 birds per replicate pen) chickens per treatment were euthanized by cervical dislocation at 51 and $46 \mathrm{~d}$ of age in Experiments 1 and 2, respectively. In Experiment 1 , the tibia and gastrocnemius tendons were carefully dissected from both legs. In Experiment 2 , only the right tibia and right gastrocnemius tendon were collected. Tibia and tendons were subjected to breaking strength using a Vernier Force Plate (Vernier Software \& Technology, Beaverton, OR, USA). The tibia was placed on an adjustable three-point loading system with a distance bone support of $60 \mathrm{~mm}$, and a vertical force was applied at midpoint by a $2.54 \mathrm{~cm}$ fulcrum. The proximal and distal portion of each tendon were fastened with sandpaper and attached to the mounting brackets of the Vernier
Force Plate. Breaking strength was recorded in newtons $(\mathrm{N})$.

Gait score (GS) and valgus/varus angulation (VAng). In Experiment 1, gait score (GS; indicator of walking ability) and valgus/varus angulation (VAng) were measured at $51 \mathrm{~d}$ of age in 15 randomly selected chickens per treatment ( 5 birds per replicate). In Experiment 2, 40 broilers per treatment (5 birds per replicate) were randomly selected at d 46 of age. Gait score was evaluated according to the methodology described by Kestin et al. (1992) and later modified by Garner et al. (2002). Six score categories (0 to 5) were used (0: broilers with a fluid locomotion; 5: completely lame broilers that cannot walk or stand). Two observers viewed and scored each bird individually. If the evaluators did not reach consensus, they had to evaluate another bird. Valgus/varus angulation (VAng) was evaluated according to the methodology described by 
Leterrier and Nys (1992). Depending on the angle size of tibia-metatarsus, four scores ( 0 to 3 ) were defined ( 0 : broilers that show no tibiametatarsus angulation evident to the naked eye -tibia-metatarsus angle less than $10^{\circ} ; 3$ : broilers with severe angulation -angle greater than $45^{\circ}$ ).

\section{Performance evaluation}

In both experiments, body weight (BW), body weight gain (BWG), feed intake (FI) and feed conversion ratio (FCR) were recorded weekly. Mortality weight gain was recorded and used to correct FCR.

\section{Statistical analysis}

The statistical model used to analyze the data was: $Y_{i j}=\mu+T_{i}+E_{i j}$; where: $Y_{i j}$ is the response variable in treatment $i$, replicate $j ; \mu$ is the general mean; $T_{i}$ is the effect of treatment $I$; and $E_{i j}$ is the random error. The TiBS and GTeBS variables were analyzed using the MIXED procedure of SAS, version 9.4 (SAS Institute, Cary, N.C., USA). The GS and VAng variables were analyzed using the GLIMMIX procedure [16]. For TiBS, GTeBS, GS and VAng the experimental unit was each individual chicken. The BW, BWG, FI and FCR were analyzed as repeated measures using the MIXED procedure, where the experimental unit was each pen replicate. Statistical differences were considered at $\mathrm{p}<0.05$.

\section{Results}

\section{Leg abnormality assessment}

Gastrocnemius tendon (GTeBS) and tibia breaking strength (TiBS). In Experiment 1, the broilers in the $17 / 3,000$ and control treatments showed similar $(p>0.05)$ GTeBS and TiBS. The birds in the 13/2,900 treatment had the lowest $(p<0.05)$ GTeBS and TiBS values with respect to the broilers in the control and $17 / 3,000$ treatments. In Experiment 2, the chickens from the $16 / 3,000$ treatment had lower $(p<0.05)$ GTeBS than the broilers from the control treatment, while TiBS was not different $(\mathrm{p}>0.05)$ between treatments (Table 3 ).
Table 3. Gastrocnemius tendon (GTeBS) and tibia (TiBS) breaking strength of broilers fed different crude protein (\% CP) and metabolizable energy (ME) levels (Exp. 1 and 2).

\begin{tabular}{ccc}
\hline \multicolumn{3}{c}{ Experiment 1 -51 d of age $(\mathbf{N}) \neq-$} \\
\hline${ }^{*}$ Treatments & GTeBS & TiBS \\
\hline $13 / 2,900$ & $121^{\mathrm{b}}$ & $250^{\mathrm{b}}$ \\
$17 / 3,000$ & $202^{\mathrm{a}}$ & $338^{\mathrm{a}}$ \\
$21 / 3,025 ;$ CON & $224^{\mathrm{a}}$ & $332^{\mathrm{a}}$ \\
SEM $^{\ddagger}$ & 9 & 16 \\
\multicolumn{3}{c}{ p-value } \\
Experiment 2 -46 d of age (N)- \\
\hline **Treatments & GTeBS & $<0.01$ \\
\hline $16 / 3,000$ & $116^{\mathrm{b}}$ & 331 \\
$21 / 3,000 ;$ CON & $158^{\mathrm{a}}$ & 347 \\
SEM & 11 & 16 \\
& $<0.01$ & p-value \\
& & 0.497
\end{tabular}

$\overline{\mathrm{a}-\mathrm{b}}$ Means within the same column without a common superscript differ $(\mathrm{p}<0.05)$

$\neq$ Newtons.

*Experiment 1, treatments: $13 \% \mathrm{CP}$ and 2,900 kcal ME kg-1 of diet, 17\% CP and 3,000 $\mathrm{kcal} \mathrm{ME} \mathrm{kg}^{-1}$ of diet and control $21 \%$ $\mathrm{CP}$ and 3,025 kcal ME kg-1 of diet.

**Experiment 2, treatments: $16 \% \mathrm{CP}$ and 3,000 kcal ME kg-1 of diet and control; 21\% CP and 3,000 kcal ME kg-1 of diet.

${ }^{\sharp} \mathrm{SEM}$; standard error of the mean.

Gait score (GS) and valgus/varus angulation (VAng). In Experiment 1, GS was affected by the diet $(p<0.01)$. When dietary CP and ME were reduced to $13 / 2,900$ a higher number of birds with a GS 4 (less walking ability) were observed compared to the control treatment. On the other hand, the birds in the 17/3,000 treatment had more cases with a GS 3 with respect to the birds in the control treatment. Similar number of GS 5 scores were observed among 13/2,900 and 17/3,000 treatments. The GS in Experiment 2 was not different $(\mathrm{p}>0.05)$ between diets (Table 4).

In Experiment 1, VAng was affected by PC and MElevels $(p<0.05)$. Broilers in the control treatment showed the lowest VAng values (scores 2 and 3) compared with the other treatments. Moreover, chickens in the 13/2,900 treatment showed higher 
VAng 2 scores (birds with obvious angulation) than birds in the control treatment. The birds in the 17/3,000 treatment had higher VAng (score 3) than chickens in the $13 / 2,900$ group. Similar to Experiment 1, the VAng was not different $(\mathrm{p}>0.05)$ between treatment diets in Experiment 2 (Table 5).

Table 4. Frequency (\%) of gait score (GS) at $51 \mathrm{~d}$ of age (Experiment 1) and at $46 \mathrm{~d}$ of age (Experiment 2) in broilers fed diets with different crude protein (\% CP) and metabolizable energy (ME) levels.

\begin{tabular}{|c|c|c|c|c|c|c|}
\hline \multirow{2}{*}{$\begin{array}{c}\text { Experiment } 1 \\
\text { *Treatments }\end{array}$} & \multicolumn{6}{|c|}{${ }^{1}$ Gait score } \\
\hline & $\mathbf{0}$ & 1 & 2 & 3 & 4 & 5 \\
\hline $13 / 2,900$ & 0.0 & 0.0 & 20.0 & 46.7 & 26.7 & 6.7 \\
\hline $17 / 3,000$ & 0.0 & 13.3 & 26.7 & 40.0 & 13.3 & 6.7 \\
\hline \multirow[t]{2}{*}{$21 / 3,025 ; \mathrm{CON}$} & 66.7 & 20.0 & 13.3 & 0.0 & 0.0 & 0.0 \\
\hline & \multicolumn{6}{|c|}{ p-value } \\
\hline
\end{tabular}

\begin{tabular}{ccccccc}
\hline Experiment 2 & \multicolumn{7}{c}{ Gait score } \\
\cline { 2 - 7 } **Treatments & $\mathbf{0}$ & $\mathbf{1}$ & $\mathbf{2}$ & $\mathbf{3}$ & $\mathbf{4}$ & $\mathbf{5}$ \\
\hline $16 / 3,000$ & 2.5 & 27.5 & 32.5 & 27.5 & 5.0 & 5.0 \\
$21 / 3,000 ;$ CON & 15.0 & 20.0 & 50.0 & 15.0 & 0.0 & 0.0 \\
& \multicolumn{2}{c}{ p-value } \\
& \multicolumn{2}{c}{0.1331} & & \\
& & & & & \\
\hline
\end{tabular}

*Experiment 1, treatments: 13\% CP and 2,900 kcal ME kg-1 of diet, 17\% CP and 3,000 kcal ME kg-1 of diet and control 21\% $\mathrm{CP}$ and 3,025 kcal ME kg-1 of diet.

**Experiment 2, treatments: $16 \% \mathrm{CP}$ and 3,000 kcal ME kg-1 of diet and control; $21 \% \mathrm{CP}$ and 3,000 kcal ME kg-1 of diet. 1Gait score: Briefly, a score of 0 denotes a bird with fluid locomotion and a furled paw when it is raised and a score of 5 denotes a bird in complete lameness that cannot walk or stand [Kestin et al. (1992) modified by Garner et al. (2002)].

Table 4. Frequency (\%) of leg valgus/varus angulation (VAng) at 51 of age (Experiment 1) and at $46 \mathrm{~d}$ of age (Experiment 2) in broilers fed with different crude protein (\% CP) and metabolizable energy (ME) levels.

\begin{tabular}{|c|c|c|c|c|}
\hline \multirow{2}{*}{$\begin{array}{l}\text { Experiment } 1 \\
\text { *Treatments }\end{array}$} & \multicolumn{4}{|c|}{ 1valgus/varus angulation (VAng) } \\
\hline & $\mathbf{0}$ & 1 & 2 & 3 \\
\hline $13 / 2,900$ & 13.3 & 33.3 & 46.7 & 6.7 \\
\hline $17 / 3,000$ & 0.0 & 66.7 & 20.0 & 13.3 \\
\hline \multirow[t]{3}{*}{$21 / 3,025 ; \mathrm{CON}$} & 13.3 & 86.7 & 0.0 & 0.0 \\
\hline & \multicolumn{4}{|c|}{$\mathrm{p}$-value } \\
\hline & \multicolumn{4}{|c|}{0.0422} \\
\hline Experiment 2 & \multicolumn{4}{|c|}{ valgus/varus angulation } \\
\hline **Treatments & $\mathbf{0}$ & 1 & 2 & 3 \\
\hline $16 / 3,000$ & 15.0 & 60.0 & 22.5 & 2.5 \\
\hline \multirow[t]{2}{*}{ 21/3,000; CON } & 30.0 & 55.0 & 12.5 & 2.5 \\
\hline & \multicolumn{4}{|c|}{ p-value } \\
\hline Treatment & \multicolumn{4}{|c|}{0.0956} \\
\hline
\end{tabular}

*Experiment 1, treatments: $13 \% \mathrm{CP}$ and 2,900 kcal ME kg-1 of diet, $17 \% \mathrm{CP}$ and 3,000 kcal ME kg${ }^{-1}$ of diet and control $21 \%$ $\mathrm{CP}$ and 3,025 kcal ME kg-1 of diet.

**Experiment 2, treatments: $16 \% \mathrm{CP}$ and 3,000 kcal ME kg-1 of diet and control; $21 \% \mathrm{CP}$ and 3,000 $\mathrm{kcal} \mathrm{ME} \mathrm{kg}^{-1}$ of diet. 1 Valgus/varus angulation was evaluated according to the methodology described by Leterrier and Nys (1992): 4 scores were defined: 0 , normal chicken; 1 , chickens with little angulation (tibia-metatarsus angle between 10 and $25^{\circ}$ ); 2 , birds with obvious angulation (angle between 25 and $45^{\circ}$ ) and 3, severe angulation (angle greater than $45^{\circ}$ ). 


\section{Performance evaluation}

In Experiment 1, broilers in the $17 / 3,000$ treatment had similar ( $>>0.05)$ BW, BWG, FI and FCR (from 2 to 7 weeks age) to the chickens fed the control diet. Broilers in the 13/2,900 treatment showed lower $(\mathrm{p}<0.05) \mathrm{BW}$ and FI than those in the control treatment (wk 3-7) (Figure 1).

In Experiment 2, broilers fed the $16 / 3,000$ diet exhibited reduced $(\mathrm{p}<0.05)$ BW at weeks 3-6 compared to the control. At week 7 no
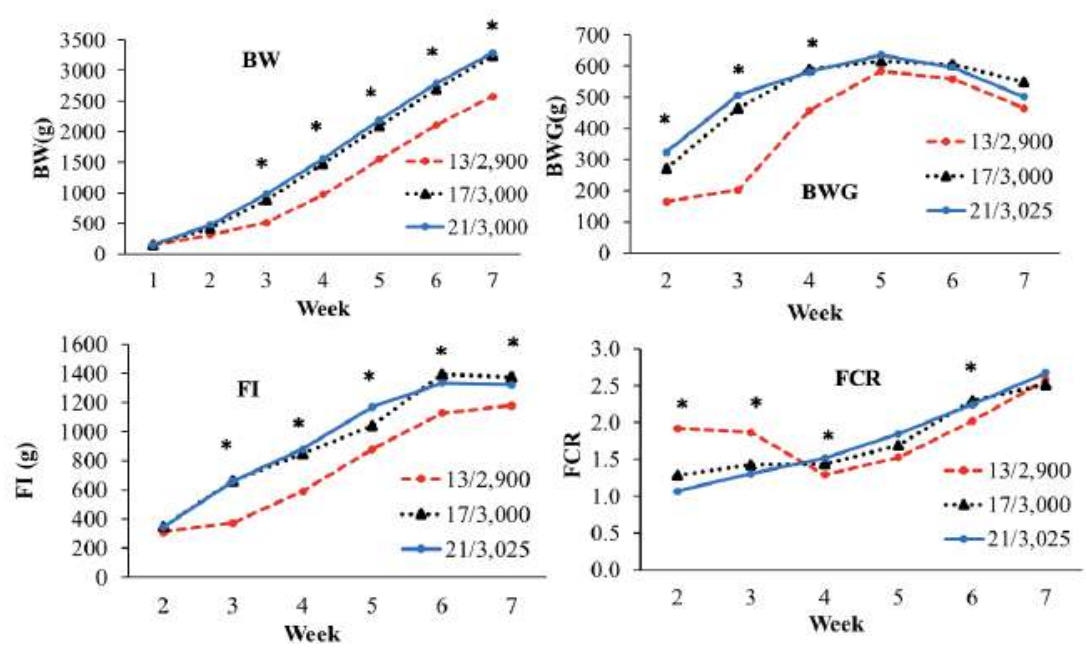

Figure 1. Performance Experiment 1. BW, body weight (g); BWG, body weight gain (g); FI, feed intake (g) and FCR, feed conversion ratio. Broilers fed diets with different $\mathrm{CP}$ and ME levels during the starter period (Treatments: $13 \% \mathrm{CP}$ and 2,900 kcal ME kg-1 of diet, 17\% CP and 3,000 kcal ME kg-1 of diet, and control, $21 \% \mathrm{CP}$ and $3,025 \mathrm{kcal} \mathrm{ME} \mathrm{kg}^{-1}$ of diet). ${ }^{*} \mathrm{p}<0.05$.
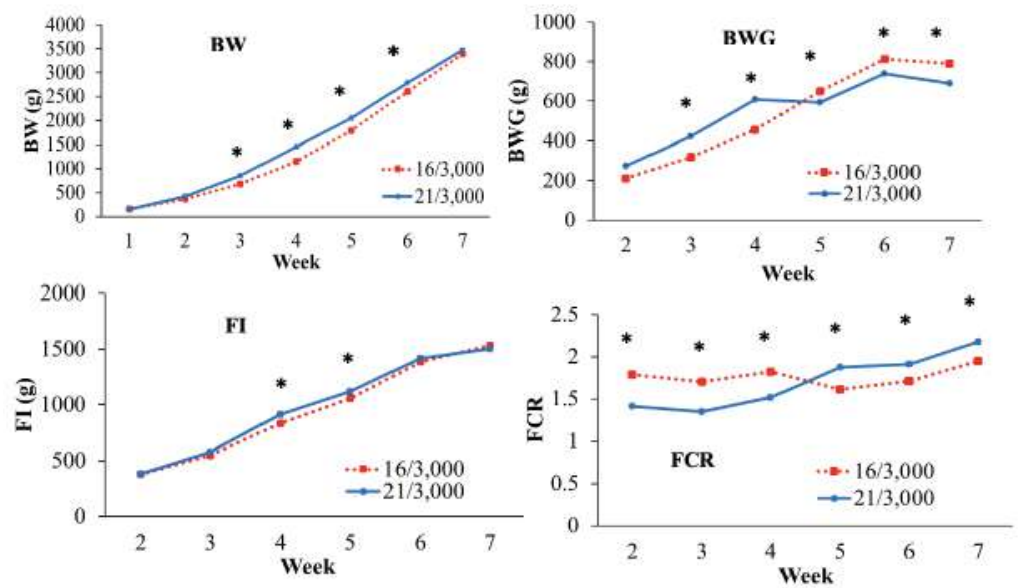

Figure2 . Performance Experiment 2, BW, Body weight (g); BWG, body weight gain (g); FI, feed intake (g) and FCR; Feed conversion ratio. Broilers fed diets with different $\mathrm{CP}$ and ME levels during the starter period (treatments: $16 \% \mathrm{CP}$ and 3,000 kcal ME kg-1 of diet and control, $21 \% \mathrm{CP}$ and 3,000 kcal ME $\mathrm{kg}^{-1} \mathrm{of} \mathrm{diet}_{\text {). }}$ $* \mathrm{p}<0.05$. 


\section{Discussion}

Results of the present study suggest that levels below 17\% CP and 3,000 kcal kg-1 ME reduce GTeBS, and concentrations below 16\% $\mathrm{CP}$ and 3,000 kcal kg-1 impair the walking ability of broilers. A high number of birds in the $13 / 2,900$ treatment showed mild to severe leg abnormalities. Research done in rats has shown that low dietary protein decreases collagen synthesis (Deyl et al., 1981) and bone mineralization (Mardon et al., 2009). Similarly, human diets that contain high levels of protein were correlated with high mineral ( $\mathrm{Ca}$ and $\mathrm{Mg}$ ) absorption and consecutively, high excretion. (McCance et al., 1942; Kerstetter et al., 2003; Dawson-Hughes et al., 2007). Thus, a relationship between amino acid type and concentration has been established with calcium homeostasis ultimately influencing bone turnover and structural protein metabolism. In the case of poultry, limited research was found regarding low dietary protein concentrations and intestinal calcium absorption. Bruno et al., 2007 concluded that when broilers are fed varying concentrations of $\mathrm{CP}$ and $\mathrm{ME}$ in the diet, it is possible to modulate the deposition of bone collagenous proteins and structure of organic components. Additionally, Bruno et al., 2007 observed that broilers fed $18.5 \% \mathrm{CP}$ and $3,200 \mathrm{kcal} \mathrm{kg}^{-1}$ of diet had lower femur width and humerus weight than broilers from control group $\left(22 \% \mathrm{CP}\right.$ and $2,950 \mathrm{kcal} \mathrm{kg}^{-1}$ of diet). The high incidence of leg abnormalities (GTeBS, TiBS, GS, VAng) and poor performance observed in the 13/2900 treatment could be explained by the low dietary protein levels used in this study. Less mineral deposition in the tibia could be the cause of deformity and reduction of breaking strength. In this study, no mineral analysis of the tibia was done; total mineral content or tibia bone ash analysis could provide more information to explain the dynamics of dietary protein and skeletal integrity in growing boiler chickens. This should be taken into consideration for further studies investigating the effect of low dietary protein in collagen synthesis and intestinal $\mathrm{Ca}$ absorption. The results of this study suggest that it is possible to reduce dietary $\mathrm{CP}$ concentration up to $17 \%$ without affecting TiBS. In agreement with these results, Yalcin et al. (1998) found that reduction from 23 to $18 \%$ CP does not affect TiBS. Collagen is the main structural component in the extracellular matrix of connective tissues such as tendons, and amino acids are the building units of proteins. Therefore, impaired collagen synthesis due to low protein intake could result in weak structural tissues and abnormalities. Type I collagen is the most abundant component in tendons (Wang, 2006). Deyl et al. (1981) reported that low protein intake affects the synthesis of Type I collagen in rats. To further investigate the effects observed in this study, where GTeBS was reduced with lower dietary protein, collagen synthesis in broiler chicks could be analyzed and provide insights on key steps being affected by low amino acid bioavailability and their relation with other nutrients such as vitamin C (Rath et al., 2000; Wu et al., 2020). Vitamin $C$ has a key role on collagen synthesis, especially in broiler chickens under heat stress (Abidin, and Khatoon, 2013); therefore, vitamin C supplementation to broiler diets could be a strategy to ameliorate the negative effects of low dietary CP levels.

In both experiments conducted in this study, low dietary CP treatment birds appeared to recover from the nutrient restriction. Broiler chickens tended to grow at similar or even higher rates compared to controls when the finisher diets were offered. Compensatory weight gain is usually present after phases or periods of nutrient restriction in young animals. Leeson et al. (1991) observed that broilers may tolerate a $7-d$ period of undernutrition during the starter period (from 4 to $11 \mathrm{~d}$ of age), and concluded that the compensatory response depends on age and the severity of the undernutrition period. The importance of feeding a nutritionally complete diet after a restriction period to observe compensatory weigh gain has been investigated by Malomo et al. (2013) who observed that birds fed with $16 \% \mathrm{CP}$ for $42 \mathrm{~d}$ had lower weight gain and higher feed conversion than those fed with $21 \%$ CP. No nutritionally complete diet was offered in the Malomo and colleagues' study 
after nutrient restriction and no compensatory weight gain was observed. On the other hand, in agreement with the results obtained in this study, compensatory weigh gain was observed in a recent study conducted by Hadaeghi et al. (2021) which involved a 14-d nutrient restriction followed by nutritionally adequate diets in broiler chickens.

Nutrient restriction is a common strategy to decrease the incidence of metabolic and skeletal disorders (Rodríguez-Ortega et al., 2014). From an animal welfare standpoint, the use of diets with low content of $\mathrm{CP}$ and ME constitutes a feed restriction method that reduces growth rate in chickens without having to restrict full access to feed and, thus, hunger (Sahraei, 2012).

In conclusion, feeding broiler chickens with $16 \% \mathrm{CP}$ and 3,000 kcal ME kg-1 of diet does not affect tibia breaking strength, gait score, valgus/ varus angulation, body weight, and feed intake of broilers. However, diets below 16\% CP and $3,000 \mathrm{kcal} \mathrm{ME} \mathrm{kg}^{-1}$ of diet reduce gastrocnemius tendon and tibia breaking strength, body weight, and feed intake of broilers. The results of the present study suggest that starter diets for broiler chickens should not be formulated below 17\% $\mathrm{CP}$ and 3,000 ME kcal kg-1 of diet.

\section{Declarations}

\section{Conflict of interest}

The authors declare they have no conflicts of interest with regard to the work presented in this study.

\section{Funding}

The author Rodríguez-Ortega L. T. expresses his gratitude to the Consejo Nacional de Ciencia y Tecnología (CONACyT-México) for the scholarship granted to carry out $\mathrm{PhD}$ studies.

\section{Author contributions}

Leodan T. Rodríguez-Ortega; experimental design, data, and sample collection, supervised the health status of the chickens and manuscript writing. Alejandro Rodríguez-Ortega; experi- mental design conceptualization. Fredy MeraZuñiga; data collection, and sample analysis in the laboratory. Arturo Pro-Martínez; conceptualization of the study. Filogonio J. HernándezGuzmán; writing, review, and editing. Eliseo Sosa-Montes; laboratory analysis. Fernando González-Cerón support on research proposal, and statistical analysis. Hector Leyva-Jimenez; manuscript writing, and final editing.

\section{References}

Abidin Z, Khatoon A. Heat stress in poultry and the beneficial effects of ascorbic acid (vitamin C) supplementation during periods of heat stress. Worlds Poult Sci J 2013; 69(1):135-152. https://doi.org/10.1017/S0043933913000123

Banerjee S, Melesse A, Dotamo E, Berihum $\mathrm{K}$, Beyan M. Effect of feeding different dietary protein levels with iso-caloric ration on nutrients intake and growth performances of dual-purpose koekoeck chicken breeds. Int J Appl Poult Res 2013; 2:27-32.

Bruno LDG, Luquetti BC, Furlan RL, Macari M. Influence of early qualitative feed restriction and environmental temperature on long bone development of broiler chickens. J Therm Biol 2007; 32:349-354. https://doi.org/10.1016/j.jtherbio.2007.04.005

Belloir P, Méda B, Lambert W, Corrent E, Juin H, Lessire M, Tesseraud S. Reducing the $\mathrm{CP}$ content in broiler feeds: impact on animal performance, meat quality and nitrogen utilization. Animal 2017; 11:1881-18. https://doi.org/10.1017/S1751731117000660

Dawson-Hughes B, Harris SS, Rasmussen HM, Dallal GE. Comparative effects of oral aromatic and branched-chain amino acids on urine calcium excretion in humans. Osteoporosis Int 2007; 18:955-61. https://doi.org/10.1007/s00198-006-0320-x

Deyl Z, Macek K, Horáková M, Adam M. The effect of food restriction and low protein diet upon collagen type I and III ration rat skin. Physiol Bohemio 1981; 30:243-250. 
Gardzielewska J, Tarasewicz Z, Dańczak A, Kwiecień J, Goluch-Koniuszy Z, Gardzielewska J, Jakubowska M, Tarasewicz Z, Szczerbińska D; Ligocki M. Meat quality of broiler quail fed on feeds with different protein content. Electron J Pol Agric Univ 2005; Available online: http://www.ejpau.media.pl/volume8/issue1/art13.html (accessed on 05 April 2019).

Garner JP, Falcone C, Wakenell P, Martin M, Mench JA. Reliability and validity of a modified gait scoring system and its use in assessing tibial dyschondroplasia in broilers. Br Poult Sci 2002; 43:355-363. https://doi.org/10.1080/00071660120103620

Hadaeghi M, Avilés-Ramírez C, Seidavi A, Asadpour L, Núñez-Sánchez N, MartínezMarín AL. Improvement in broiler performance by feeding a nutrient-dense diet after a mild feed restriction. Rev Colomb Cienc Pecu 2021; 34(3). Pages pending. https://doi.org/10.17533/udea.rccp.v34n3a02

Jackson S, Summers JD, Leeson S. Effect of dietary protein and energy on broiler performance and production costs. Poult Sci 1982; 61(11):2232-2240.

KerstetterJE,BrienKOO,InsognaKL.Lowprotein intake: theimpactoncalciumand bonehomeostasis in humans. J Nutr 2003; 133:855S-861S. https://doi.org/10.1093/jn/133.3.855S

Kestin SC, Knowles TG, Tinch AE, Gregory NG. Prevalence of leg weakness in broiler chickens and its relationships with genotype. Vet Rec 1992; 131:190-194.

Leeson S, Summers JD, Caston LJ. Diet dilution and compensatory growth in broilers. Poult Sci 1991; 70:867-873. https://doi.org/10.3382/ps.0700867

Leterrier C, Nys Y. Clinical and anatomical differences in varus and valgus deformities of chick limbs suggest different aetiopatogenesis. Aviar Pathol 1992; 21:429-442. https://doi.org/ 10.1080/03079459208418861
Malomo GA, Bolu SA, Olutade SG. Effects of dietary crude protein on performance and nitrogen economy of broilers. Sustain Agric Res 2013; 2:52-57. https://doi.org/10.22004/ag.econ.230555

Mardon J, Trzeciakiewicz A, Habauzit V, Davicco M-J, Lebecque P, Mercier S, Tressol J-C, Horcajada M-N, Demigné C, Coxam V. Dietary protein supplementation increases peak bone mass acquisition in energy-restricted growing rats. Pediatr Res 2009; 66:513-518. https://doi.org/10.1203/PDR.0b013e3181b9b4bb

McCance RA, Widdowson EM, Lehmann H. The effect of protein intake on the absorption of calcium and magnesium. Biochem J 1942; 36:686-691.

National Research Council. Nutrient requirements of poultry. 9th ed. Washington (DC): National Academy of Sciences, 1994, p. 174.

Norma Oficial Mexicana. NOM-062-ZOO-1999. Especificaciones técnicas para la producción, cuidado y uso de animales de laboratorio. Ochoa M. L. I. Diario Oficial de la Federación: México, DF; 2001.

Norma Oficial Mexicana. NOM-033-SAG/ZOO2014. Métodos para dar muerte a los animales domésticos y silvestres. Diario Oficial de la Federación. México DF; 2015.

Rath NC, Huff GR, Huff WE, Balog JM. Factors regulating bone maturity and strength in poultry. Poult Sci 2000; 79(7):1024-1032. https://doi.org/10.1093/ps/79.7.1024

Rodríguez-Ortega LT, Sosa-Montes E, ProMartínez A, Ruiz-Feria CA, Bautista-Ortega J, Vargas-Galicia AJ, Chan-Díaz D, PérezHernández P. Free access to feed reduces the antioxidative capacity in broilers raised at high altitudes. Poult Sci 2014; 93 (E-Supp. 1)77.

Sahraei M. Feed restriction in broiler chicken production. Biotechnol. Anim. Husb. 2012; 28:33-352. https://doi.org/10.2298/BAH1202333S 
SAS Institute. Language guide for personal computers, release 9.4 Edition. SAS Institute Cary N. C. USA 2013. p.1028.

Venäläinen E, Valaja J, Jalava T. Effects of dietary metabolizable energy, calcium and phosphorus on bone mineralization, leg weakness and performance of broiler chickens. Br Poult Sci 2006; 47: 301-310. https://doi.org/10.1080/00071660600741776

Wang HCJ. Mechanobiology of tendon. J Biomech 2006; 39:1563-1582. https://doi. org/10.1016/j.jbiomech.2005.05.011

$\mathrm{Wu} \mathrm{M}$, Cronin K, Crane JS. Biochemistry, Collagen Synthesis. In: StatPearls. Treasure Island (FL):

StatPearls Publishing; 2020 Jan-. Available from: https:/www.ncbi.nlm.nih.gov/books/NBK507709/

Yalcin S, Settar P, Dicle O. Influence of dietary protein and sex on walking ability and bone parameters of broilers. $\mathrm{Br} \quad$ Poult Sci 1998; 39:251-256.

https://doi.org/ 10.1080/0007166988921 